Piotr IGNACIUK

\title{
Chosen aspects of biofuel usage on the example of camelina oil methyl ester
}

\begin{abstract}
Camelina is the oil plant, from which the oil subjected to the esterification process can be used as motor fuel to diesel engines or as a bio-component added to traditional fuels. This fuel can be considered as a renewable fuel that can be bio-component for petroleum fuels. The article describes the characteristics of this fuel, and presents selected results of engine tests of camelina oil methyl ester compared with diesel fuel and rapeseed oil methyl esters. The interesting results that would require in the future to increase the interest in this type of fuel were obtained.
\end{abstract}

Key words: biofuels, camelina, Diesel engine, exhaust emissions, emissions tests

\section{Wybrane aspekty stosowania biopaliw na przykladzie estrów metylowych oleju Inianki}

Lnianka jest roślina oleista, z której olej poddany procesowi estryfikacji może być używany jako paliwo silnikowe silników o zapłonie samoczynnym lub jako biokomponent dodawany do tradycyjnych paliw. Paliwo to może być rozpatrywane jako jedno z paliw odnawialnych, mogacych stanowić biokomponent paliw ropopochodnych. W artykule opisano właściwości tego paliwa oraz przedstawiono wybrane wyniki badań silnikowych estrów metylowych oleju lnianki w porównaniu z olejem napędowym oraz estrami metylowymi oleju rzepakowego. Uzyskano interesujące wyniki, które nakazywatyby w przyszłości zwiększyć zainteresowanie tym rodzajem paliwa.

Słowa kluczowe: biopaliwa, lnianka siewna, silnik o zapłonie samoczynnym, emisja związków toksycznych, testy emisji

\section{Introduction}

During last years a tendency can be observed to replace fossil resources with renewable ones. One of the symptoms of this trend is replacing liquid fuels derived from crude oil with fuels obtained from plants and animals. One of the most important reasons of fuel replacement are reduced availability of crude oil and ecological aspects. Biofuels and biocomponents of engine fuels are easily biodegradable and without any harm can be introduced into existing ecosystems.

\section{Camelina seed as a material for biofuel production}

Common usage of biofuels is possible only if their wide scale production begins. Therefore it is necessary to find generous and easily accessible source of material, which will fulfill basic criteria:

- will be inexpensive in cultivation,

- will not compete with cultivation of crops for food,

- will not diminish agricultural areas.

In the light of the requirements above, finding the right stock is rather difficult. Cited conditions can be fulfilled only by not numerous stocks, mainly waste vegetable oils and fats of biological origin. These oils not always have proper quality and are available in the desired quantity.

One of the oil plants which has chances to fulfill above criteria is camelina seed (Camelina sativa). Camelina, because of low soil and climate requirements can be cultivated on the areas which are inappropriate for the plants used for consumption purposes. A stock for the biofuel production can be plant oil derived from camelina or green part of the

\section{Wprowadzenie}

W ostatnich latach zaznacza się tendencja do zastępowania surowców kopalnych surowcami odnawialnymi. Jednym z przejawów tej tendencji jest zastępowanie ropopochodnych paliw płynnych paliwami otrzymywanymi z roślin i zwierząt. Do najważniejszych przyczyn zastępowania surowców kopalnych przez surowce odnawialne należą: kurczące się łatwe do pozyskania zasoby surowców kopalnych oraz względy ekologiczne. Biopaliwa i biokomponenty paliw silnikowych łatwo ulegają biodegradacji i bez szkody mogą być wprowadzone do ekosystemów.

\section{Lnianka siewna jako surowiec do produkcji biopaliw}

Powszechne zastosowanie biopaliw jest możliwe tylko pod warunkiem uruchomienia ich produkcji na szeroką skalę. Konieczne jest zatem znalezienie obfitego i łatwo dostępnego źródła pozyskiwania surowca, który spełni podstawowe kryteria: nie będzie drogi $w$ uprawie, nie będzie konkurować z uprawami na cele spożywcze, nie uszczupli areałów rolniczych.

Znalezienie odpowiedniego surowca jest bardzo trudne. Przytoczone warunki mogą być spełnione jedynie przez nieliczne dostępne surowce, głównie odpadowe oleje i thuszcze pochodzenia biologicznego. Oleje takie jednak nie zawsze mają odpowiednią jakość, a ich dostępność jest ograniczona.

Jedną z roślin oleistych, która ma możliwości spełnienia powyższych kryteriów jest lnicznik siewny (Camelina sativa), popularnie zwany lnianką (spotykana jest też nazwa zwyczajowa rydz). Lnianka, z uwagi na małe wymagania 


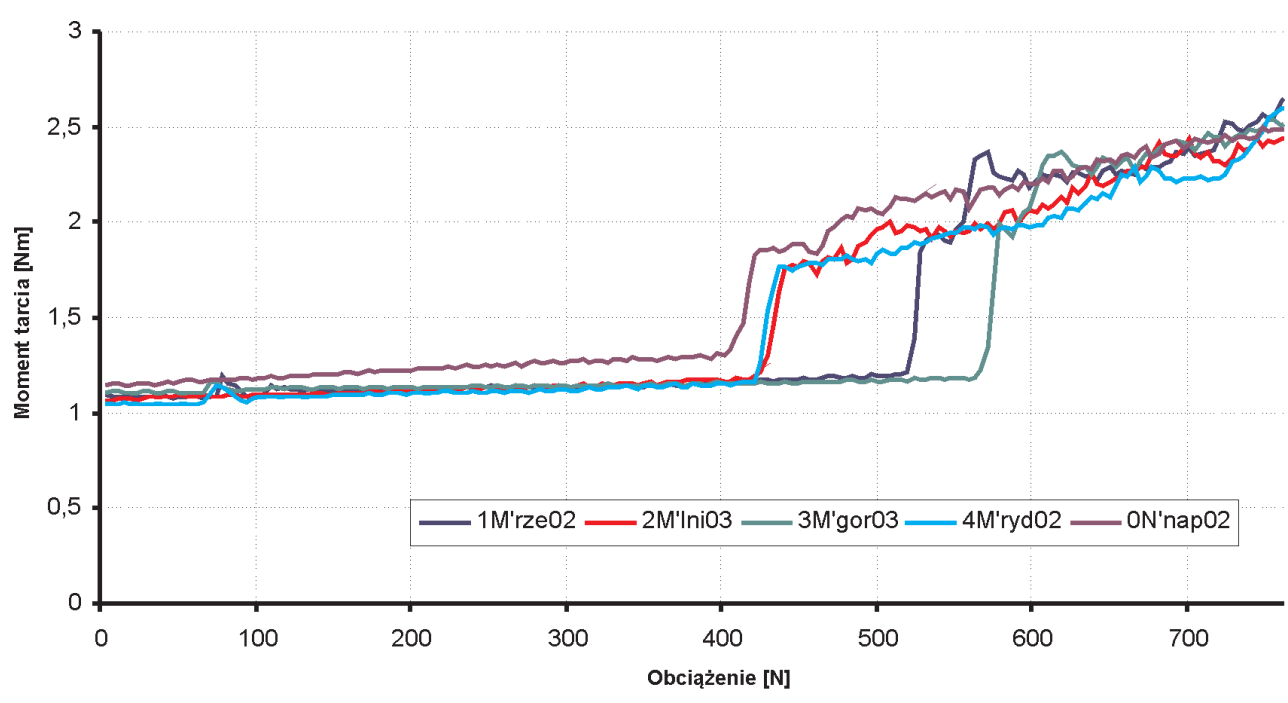

Fig. 1. Comparison of seizing load for methyl esters of plant oils and diesel fuel (moment tarcia = friction torque; obciążenie $=$ load)

Rys. 1. Porównanie obciążenia zacierającego dla estrów metylowych z olejów roślinnych oraz oleju napędowego

plant. Now in Poland the most popular biofuels are fatty acid methyl esters (FAME) made from rapeseed oil, they are used mostly as additives to the diesel fuel. Rapeseed esters are made in the transestrification process of the plant oil with methanol in the presence of basic catalysts. Camelina oil can be used also for methyl ester production in the similar way as from the rape oil.

\section{Chosen properties of camelina oil methyl esters}

Methyl esters of camelina oil in comparison to the rapeseed methyl esters and conventional diesel fuel can be characterized by the good lubricity and low kinematic viscosity. Friction torque courses which determine seizing load for camelina oil methyl esters (M'ryd02) and for the flax oil methyl ester (M'lni02) which are shown in Fig. 1 are close to ones obtained for the diesel fuel. Methyl esters obtained from rapeseed oil (M'rze02) and other examined oils show higher values of seizing load. These values allow for conclusion, that lubricating properties of fuels made on the basis of methyl esters of plant oils can provider better anti-wear protection than diesel fuel.

Fuel viscosity determines its atomization during the injection process, what directly influences the course of combustion in a Diesel engine. In case of injection of the fuel with high

Table 1 . Kinematic viscosity and density of some plant oils and their esters at $20 / 40{ }^{\circ} \mathrm{C}$

Tabela 1. Wartości lepkości kinematycznej i gęstości wybranych olejów roślinnych i ich estrów w temperaturze $20 / 40{ }^{\circ} \mathrm{C}$

\begin{tabular}{|c|c|c|}
\hline Oil/olej & $\begin{array}{c}\text { Density at/gęstość } w \\
20^{\circ} \mathrm{C}\left[\mathrm{kg} / \mathrm{dm}^{3}\right]\end{array}$ & $\begin{array}{c}\text { Kinematic viscosity at/lepkość } \\
\text { kinematyczna } w 40^{\circ} \mathrm{C}\left[\mathrm{mm}^{2} / \mathrm{s}\right]\end{array}$ \\
\hline Diesel fuel/ON & 0.84 & $2.0-4.5$ \\
\hline Rapeseed Oil/rzepakowy & 0.92 & 35.24 \\
\hline Camelina sativa/lnianki & 0.89 & 30.17 \\
\hline \multicolumn{2}{|c|}{ Methyl esters/estry metylowe olejów roślinnych } \\
\hline Rapeseed ME/rzepakowy & 0.83 & 5.28 \\
\hline Camelina ME/lnianki & 0.88 & 5.18 \\
\hline
\end{tabular}

glebowe i klimatyczne może być uprawiana na areałach, które nie nadają się do uprawy roślin przeznaczonych na cele spożywcze. Surowcem do produkcji biopaliw może być olej lnianki oraz część zielna rośliny. Obecnie w Polsce jako biopaliwa najbardziej rozpowszechnione są estry metylowe kwasów tłuszczowych, które wytwarza się głównie z oleju rzepakowego. Znajdują one zastosowanie przede wszystkim jako biokomponent olejów napędowych do silników ZS. Otrzymuje się je w wyniku transestryfikacji tłuszczów metanolem, którą prowadzi się w obecności katalizatorów zasadowych. Z oleju lnianki można wytwarzać estry metylowe w podobny sposób jak z oleju rzepakowego.

\section{Wybrane właściwości estrów metylowych oleju Inianki}

Estry oleju lnianki w odniesieniu do estrów oleju rzepakowego oraz do klasycznego oleju napędowego charakteryzuje dobra smarność oraz w miarę niska lepkość kinematyczna. Przedstawione na rysunku 1 przebiegi momentu tarcia, wyznaczające wartość obciążenia zacierającego dla estrów metylowych oleju lnianki (ozn. M'ryd02) oraz dla estru z oleju lnianego (M'lni02), są zbliżone do wartości uzyskanych dla oleju napędowego. Estry metylowe z oleju rzepakowego (M'rze02) i oleju gorczycowego (M'gor03) wykazują większe wartości obciążenia zacierającego. Uogólniając, można stwierdzić, że zdolności smarne paliw wytworzonych na bazie estrów olejów roślinnych powinny zapewniać większą ochronę przeciwzużyciową niż czysty olej napędowy.

Bardzo ważną właściwością paliw do zasilania silników ZS jest lepkość - tab. 1. Lepkość paliwa decyduje o stopniu jego rozpylenia, co wpływa na przebieg procesu spalania. W przypadku wtrysku paliwa o dużej lepkości tworzą się krople o większych średnicach, a silnik charakteryzuje się większym zadymieniem. Wyższa lepkość paliwa utrudnia też jego filtrowanie.

\section{Estry metylowe oleju Inianki jako paliwo do silników ZS}

Estry metylowe olejów roślinnych charakteryzują się wysoką, w porównaniu do olejów napędowych, liczbą cetanową (rzędu 55 jednostek) oraz wyższą lepkością. W warunkach zimowych, z powodu bardzo dużego wzrostu lepkości, stosowanie estrów olejów roślinnych jest możliwe dopiero po wprowadzeniu dodatków obniżających lepkość. Olej lnianki w 
viscosity, droplets with high diameter are formed, and engine has higher emission of particulates. Moreover higher viscosity of the fuel makes its filtration more difficult.

\section{Methyl esters of camelina oil as fuel for diesel engines}

Methyl esters of vegetable oils have high - in comparison to the diesel fuel - cetane number (55 units) and higher viscosity. In winter conditions, because of very high increase of viscosity, application of methyl esters is possible after introduction of additives which depress the viscosity. Camelina oil, in comparison to the rapeseed oil much has higher content of fatty acids with three non-saturated bonds and complex hydrocarbon chains. It has also much higher content of fatty acids $\mathrm{C} 20$ - i.e. $18 \%$, whereas rapeseed oil has only about $2 \%$. Presence of multi non-saturated complex fatty acids results in the decrease of solidification point of the oil itself and its methyl esters as well. Fatty chains, because of their compound shape, much more difficult bond into compound complexes during the reduction of temperature, hence camelina oil has a low freezing point (below $-18^{\circ} \mathrm{C}$ ).

Production, transport and distribution of esters requires maintaining proper parameters in order to protect against humidity. All methyl esters of vegetable oils can accumulate up to 40 times more water than diesel fuel and have decreased resistance to oxidation, what is of great significance during long-term storage. It was proved, that water present in esters in quantity above $300 \mathrm{mg} / \mathrm{kg}$ is a reason of intensive development of bacteria, what reduces stability of this fuel. The presence of ester compound, which makes this fuel similar to certain types of varnishes and plastics results in its ability to dissolve certain types of varnishes and rubber seals, what can produce problems during vehicle operation [3].

Esters of vegetable oils have the possibility to mix in any proportion with diesel fuel. It is one of the most significant properties, decisive in the common usage of methyl esters as bio-components of diesel fuels. Using methyl esters as bio-components compensates for lack of sulfur compounds as natural lubricating components, what drastically worsens lubricty of these fuels and forces usage of synthetic additives. Biofuels are more eco-friendly as emitted carbon dioxide comes from the natural carbon cycle on earth. Biofuels have high biodegradability, and in case of water porównaniu do oleju rzepakowego, charakteryzuje się znacznie większą zawartością kwasów thuszczowych o trzech wiązaniach nienasyconych i złożonych łańcuchach węglowodorowych. Zawiera on także znacznie większą ilość kwasów tłuszczowych C20, bo około $18 \%$, podczas gdy w oleju rzepakowym znajduje się ich tylko około 2\%. Obecność wielonienasyconych kwasów tłuszczowych o złożonej budowie powoduje obniżenie temperatury krzepnięcia zarówno samego oleju, jak i sporządzonych z niego estrów metylowych. Łańcuchy te z uwagi na złożoność kształtów trudniej łączą się w kompleksy podczas obniżania temperatury, stąd olej lnianki charakteryzuje niska temperatura krzepnięcia (poniżej $-18^{\circ} \mathrm{C}$ ).

Produkcja, transport i dystrybucja estrów wymaga zachowania należytych parametrów w celu zabezpieczenia ich przed wpływem wilgoci. Wszystkie estry metylowe olejów roślinnych mogą wchłonąć około 40 razy więcej wody niż olej napędowy i charakteryzują się zmniejszoną odpornością na utlenianie, co ma szczególne znaczenie przy długim okresie przechowywania. Stwierdzono, że zawartość wody w estrach powyżej $300 \mathrm{mg} / \mathrm{kg}$ jest przyczyną znacznego wzrostu bakterii, co pogarsza stabilność tego paliwa. Obecność grupy estrowej upodabniającej chemicznie biopaliwo do niektórych lakierów oraz tworzyw sztucznych powoduje skłonność tego paliwa do rozpuszczania lakierów i uszczelnień gumowych, co stwarza problemy w eksploatacji [3].

Estry olejów roślinnych mają możliwość mieszania się $\mathrm{w}$ dowolnych proporcjach $\mathrm{z}$ olejem napędowym. Jest to jedna $\mathrm{z}$ najistotniejszych właściwości, które zadecydowały o powszechnym stosowaniu estrów jako biokomponentu do paliw silników ZS. Ponadto stosowanie estrów jako biokomponentu rekompensuje obniżenie zawartości związków siarki we współczesnych paliwach. Ograniczenie zawartości siarki drastycznie pogarsza poziom właściwości smarnych paliw i powoduje konieczność stosowania syntetycznych dodatków. Biopaliwa są bardziej przyjazne środowisku, bowiem ich spalaniu towarzyszy emisja dwutlenku węgla pochodzącego z naturalnego obiegu węgla w przyrodzie. Biopaliwa charakteryzują się bardzo dużą biodegradowalnością; w sytuacji przedostania się do gruntu lub wody nie powodują skażenia. Tradycyjne paliwa ropopochodne zawierają mniej tlenu oraz stanowią bardzo skomplikowane mieszaniny węglowodorów z wielokrotnymi wiązaniami podwójnymi, a także łańcuchami cyklicznymi. Taka struktura cząstecz-

Table 2. Technical specifications of the diesel engines: 1,4D-4D and 4CT90

Tabela 2. Dane techniczne silników: 1,4D-4D i 4 CT90

\begin{tabular}{|c|c|c|}
\hline Engine/parameter & $1,4 \mathrm{D}-4 \mathrm{D}$ & 4СТ90 \\
\hline Displacement/objętość skokowa & $1364 \mathrm{ccm}$ & $2417 \mathrm{ccm}$ \\
\hline Max. power/moc maks. & $66,2 \mathrm{~kW}$ at $3800 \mathrm{rpm} / \mathrm{obr} / \mathrm{min}$ & $66 \mathrm{~kW}$ at $4100 \mathrm{rpm} / \mathrm{obr} / \mathrm{min}$ \\
\hline Max. torque/moment maks. & $190 \mathrm{Nm}$ from/w zakresie 1800 to $3000 \mathrm{rpm} / \mathrm{obr} / \mathrm{min}$ & $195 \mathrm{Nm}$ from/przy $2500 \mathrm{rpm} / \mathrm{obr} / \mathrm{min}$ \\
\hline Compression ratio/stopień sprężania & 17.9 & 20.6 \\
\hline $\begin{array}{l}\text { Fuel injection system/system wtrysku } \\
\text { paliwa }\end{array}$ & $\begin{array}{c}\text { Common Rail (1600 bar), } 6 \text { hole injectors/wtryski- } \\
\text { wacze 6-otworowe }\end{array}$ & $\begin{array}{c}\text { line pump MOTORPAL, indirect injection/pompa } \\
\text { rzędowa MOTORPAL, wtrysk pośredni do komory } \\
\text { wirowej }\end{array}$ \\
\hline $\begin{array}{l}\text { Exhaust gas treatment } / \text { uktad oczysz- } \\
\text { czania spalin }\end{array}$ & $\begin{array}{l}\text { EGR, equipped with cooler and catalyst/chłodnica } \\
\text { tadunku oraz filtr czastek statych }\end{array}$ & EGR \\
\hline Emission standard/norma emisji & Euro IV & Euro II \\
\hline
\end{tabular}


or earth penetration, the leakage does not create contamination. Conventional fuels derived from crude oil have less oxygen content and constitute very complicated mixtures of hydrocarbons with multiple double bonds and cyclic chains. Such complicated molecular structure determines their low biodegradability and high toxicity. Domination of diesel fuel in the fuel consumption created additional possibilities to increase the share of fuels obtained from oilseeds.

\section{Experimental engine research}

So as to have deeper knowledge about functional properties of methyl esters of camelina seed external characteristics and emission tests of some toxic compounds were made. Research of operational properties was made at Institute of Automotive Transport in Warsaw. During research a comparison between engine parameters fueled with diesel oil (ON) and methyl esters of rape (B100) and camelina (EL) was made. The research object was 4CT90 DI engine and Toyota Yaris with turbocharged engine 1,4D-4D.

Comparison of full load characteristics engines: 4CT90 (Fig. 2) and 1.4D-4D (Fig. 3) fuelled with investigated fuels it can be observed that higher torque and power obtained for the engine fuelled with esters B100 and EL is accompanied with higher specific fuel consumption than in the case of diesel fuel. It should be stated that in both cases engine was run with the same position of bar controlling fuel dosage. Increased specific fuel consumption can result from the higher density of both bio fuel it and their lower than diesel fuel calorific value. In general can be concluded that:

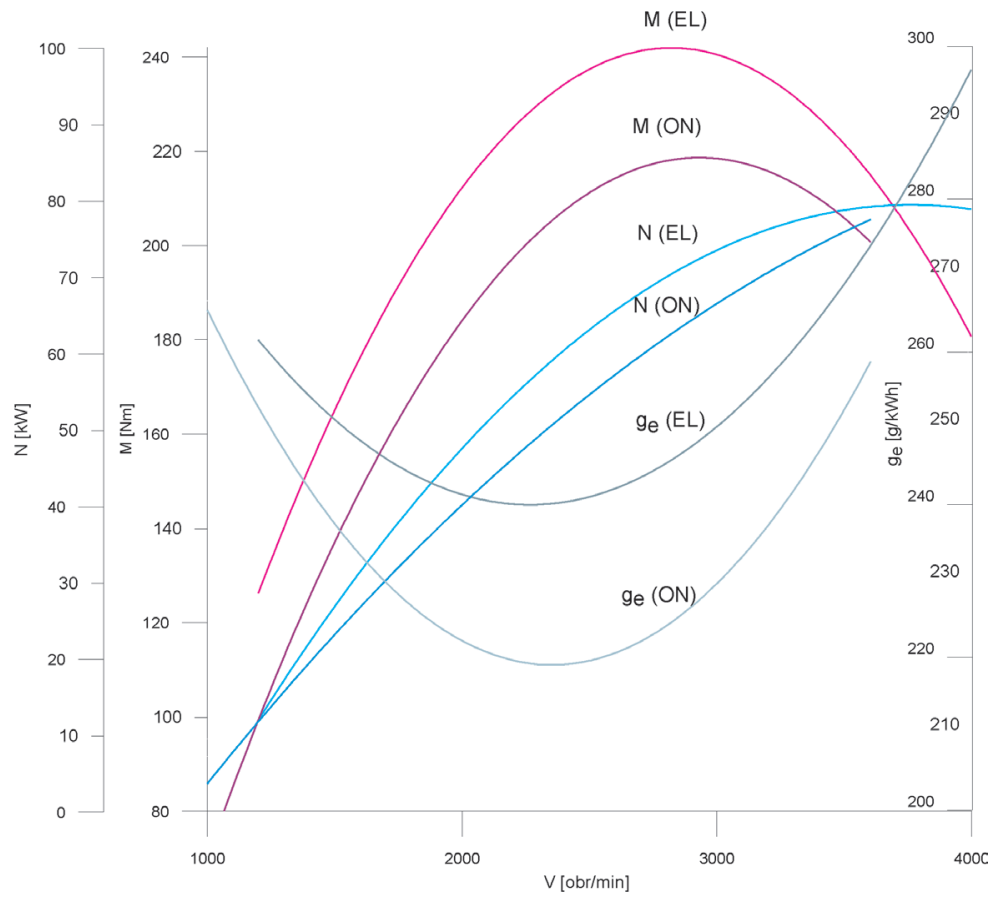

Fig. 2. Comparison of 4CT90 engine full load characteristics fuelled with diesel fuel and EL [4] Rys. 2. Porównanie charakterystyk zewnętrznych silnika 1.4D-4D zasilanego EL i ON [4]

kowa decyduje o ich małej biodegradowalności oraz dużej toksyczności. Dominacja oleju napędowego w konsumpcji paliw stwarza dodatkowe możliwości zwiększenia udziału paliw pochodzących z roślin oleistych.

\section{Badania silnikowe}

W celu szerszego poznania właściwości użytkowych estrów metylowych oleju lnianki wykonano charakterystyki

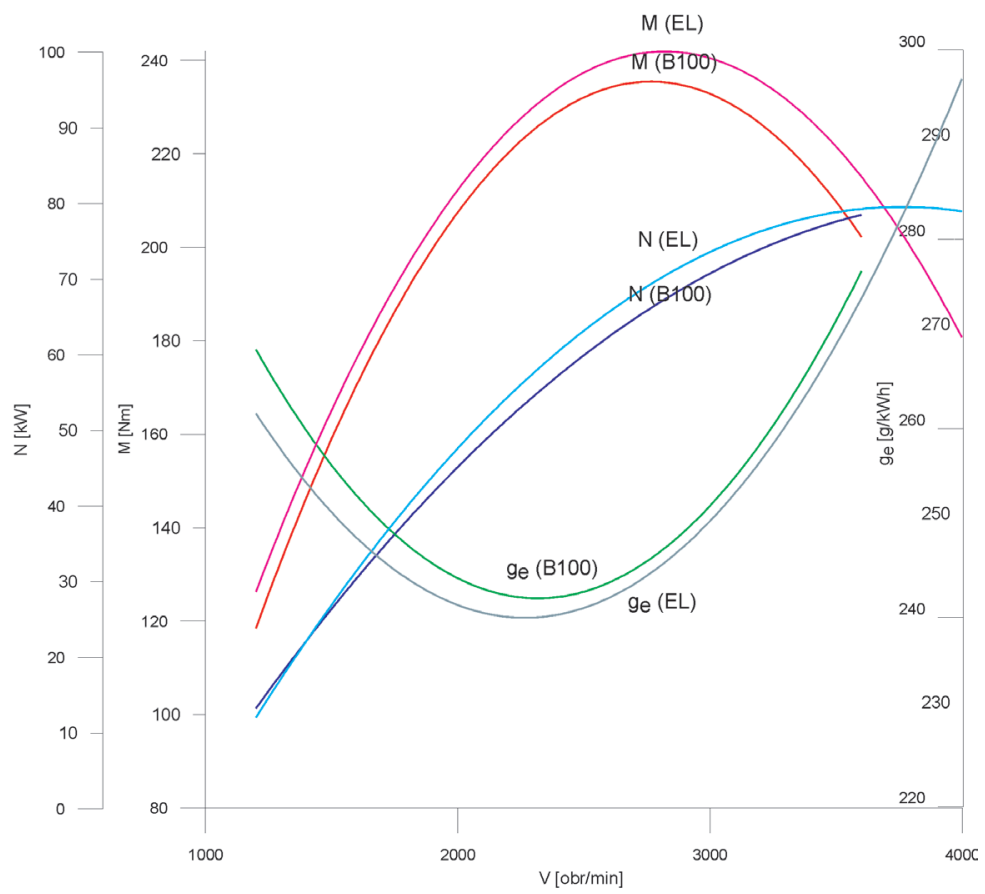

Fig. 3. Comparison of 1.4D-4D engine full load characteristics fuelled with EL and B100 [4] Rys. 3. Porównanie charakterystyk zewnętrznych silnika 1.4D-4D zasilanego EL i B100 [4] zewnętrzne silnika oraz testy emisji wybranych związków toksycznych. Badania właściwości eksploatacyjnych przeprowadzono w Instytucie Transportu Samochodowego w Warszawie. Prace badawcze polegały na porównaniu parametrów silnika zasilanego: estrami lnianki (EL), estrami rzepakowymi (B100) i olejem napędowym (ON). Jako obiekty badań wykorzystano silnik 4CT90 oraz Toyotę Yaris z silnikiem turbodoładowanym 1,4 D-4D o pojemności skokowej $1364 \mathrm{~cm}^{3}$ (tab.2).

Porównując charakterystyki zewnętrzne silników: 4CT90 (rys. 2) i 1,4D-4D (rys. 3) zasilanych badanymi paliwami, można zauważyć, że większym momentom i mocom uzyskiwanym podczas zasilania silnika estrami B100 i EL towarzyszy większe jednostkowe zużycie paliwa niż przy zasilaniu olejem napędowym. Należy zaznaczyć, że w obu przypadkach silnik pracował z jednakowym położeniem listwy sterującej dawkowaniem paliwa. Zwiększone jednostkowe zużycie paliwa $\mathrm{g}_{\mathrm{e}}$ może wynikać z większej gęstości porównywanych biopaliw i ich mniejszej, w stosunku do ON, wartości opałowej. Ogólnie można stwierdzić, iż: 
- maximum torque and engine power were obtained for engine fuelling with camelina methyl esters,

- specific fuel consumption was maximum when engine was fuelled with rapeseed methyl esters,

- minimum torque and engine power were obtained for diesel fuel.

Figures $4-7$ show results of emission research carried out according to the ETC (European Transient Cycle) and ESC (European Stationary Cycle) and NRTC (Non Road Test Cycle). The results allow for the following remarks:

- hydrocarbons emission for all investigated fuels was on a comparable level,

- emission of particulate matter was highest for camelina esters,

- nitrogen oxides emission was highest in ETC and NRTC tests when engine was fuelled with camelina esters, in ESC test it was lower than for B100 fuel,

- in all tests $\mathrm{NO}_{\mathrm{x}}$ emission was higher when engine was fuelled with biofuels than with diesel fuel,

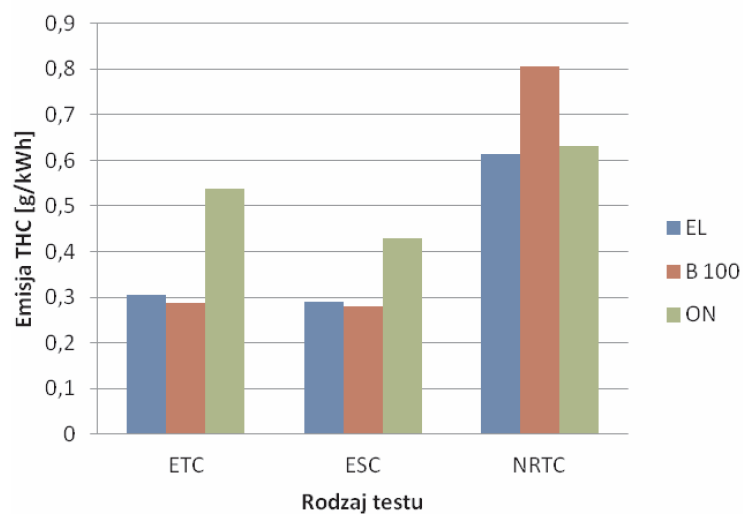

Fig. 4. THC emissions in ETC, ESC and NRTC cycles, engine fuelled with EL, B100 and Diesel fuel

Rys. 4. Porównanie emisji węglowodorów w testach ETC, ESC i NRTC przy zasilaniu silnika EL, B100 i ON

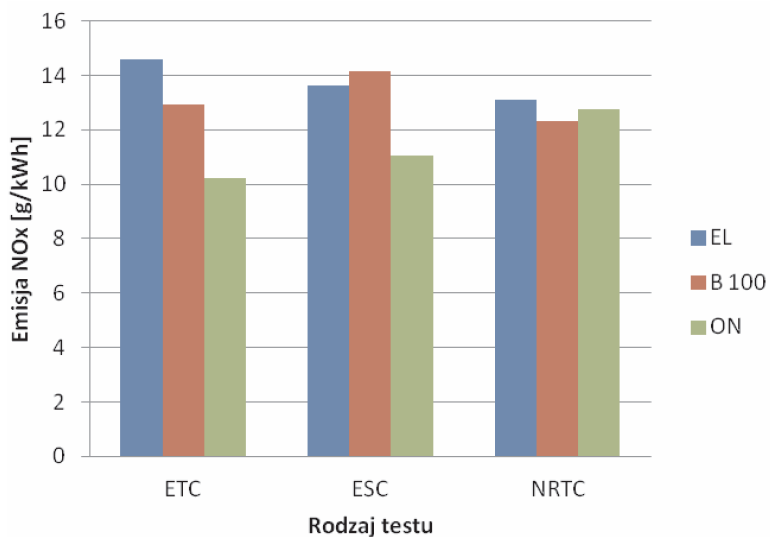

Fig. 6. $\mathrm{NO}_{\mathrm{x}}$ emissions in ETC, ESC and NRTC cycles, engine fuelled with EL, B100 and Diesel fuel

Rys. 6. Porównanie emisji tlenków azotu w testach ETC, ESC i NRTC przy zasilaniu silnika EL, B100 i ON
- najwyższy moment obrotowy i moc silnika uzyskano przy zasilaniu silnika estrami lnianki,

- najwyższe jednostkowe zużycie paliwa uzyskano przy zasilaniu silnika estrami rzepakowymi,

- silnik zasilany olejem napędowym uzyskał najmniejszą moc oraz moment obrotowy.

Na rysunkach $4-7$ przedstawiono wyniki badań emisji wykonane według testów ETC (European Transient Cycle), ESC (European Stationary Cycle) i NRTC (Non-Road Test Cycles). Otrzymane wyniki pozwalają stwierdzić, że:

- emisja węglowodorów dla wszystkich badanych paliw jest na zbliżonym poziomie,

- emisja cząstek stałych jest największa dla estrów lnianki,

- emisja tlenków azotu przy zasilaniu estrami lnianki jest największa $\mathrm{w}$ teście ETC i NRTC, natomiast $\mathrm{w}$ teście ESC jest nieco mniejsza niż przy zasilaniu paliwem rzepakowym B100.

- we wszystkich testach emisja tlenków azotu jest większa przy zasilaniu silnika biopaliwami, niż przy zasilaniu silnika olejem napędowym,

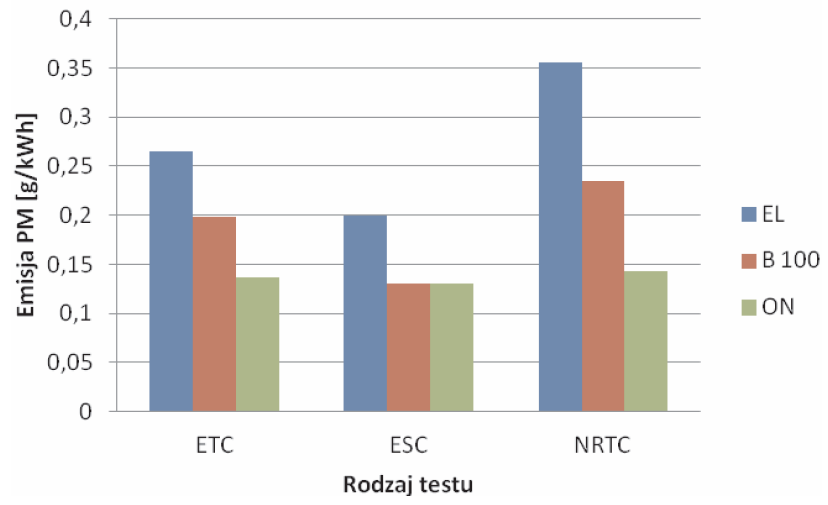

Fig. 5. PM emissions in ETC, ESC and NRTC cycles, engine fuelled with EL, B100 and Diesel fuel

Rys. 5. Porównanie emisji cząstek statych w testach ETC, ESC i NRTC przy zasilaniu silnika EL, B100 i ON

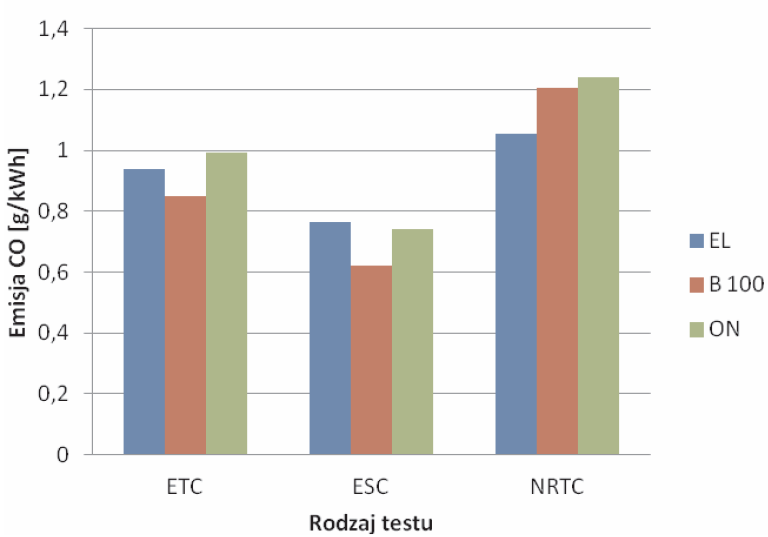

Fig. 7. CO emissions in ETC, ESC and NRTC cycles, engine fuelled with EL, B100 and Diesel fuel

Rys. 7. Porównanie emisji tlenku węgla w testach ETC, ESC i NRTC przy zasilaniu silnika EL, B100 i ON 
- in case of CO emission, it was lowest for the camelina esters in NRTC test, for the remaining tests it was at a comparable level.

\section{Conclusions}

The analysis of the obtained data shows that the examined biofuels can be successfully used to power internal combustion engines. Esters of camelina and rapeseed esters cause improvement in course of load characteristics but an specific fuel consumption also higher this results from the increased density of biofuels and their lower calorific value compared to ON. When comparing the results of emissions it can be concluded that biofuels generally produced higher levels of exhaust emissions, with the exception of $\mathrm{CO}$ emissions (for all the cycles) and THC (for ETC cycle).

Paper reviewed/Artykut recenzowany
- emisja tlenku węgla jest najmniejsza dla estrów lnianki w teście NRTC, w pozostałych testach jest porównywalna do innych badanych paliw.

\section{Wnioski}

Z analizy otrzymanych danych wynika, że badane biopaliwa mogą być z powodzeniem stosowane do zasilania silników spalinowych. Estry lnianki i estry rzepakowe powodują poprawę charakterystyk pracy silnika przy jednoczesnym pogorszeniu przebiegu jednostkowego zużycia paliwa. Zwiększanie tego wskaźnika prawdopodobnie wynika z większej gęstości porównywanych biopaliw i ich mniejszej wartości opałowej w stosunku do ON. Przy porównaniu otrzymanych wyników emisji można stwierdzić, iż emisja związków toksycznych jest wyższa w przypadku biopaliw; jedynie dla $\mathrm{CO}$ we wszystkich testach oraz dla THC w teście ETC uzyskano większe wartości podczas zasilania ON.
Abbreviations and nomenclature/Wykaz skrótów i oznaczeń
B100 Biodiesel made from vegetable oil or animal fats/biodie- sel wyprodukowany z oleju roślinnego lub tluszczów zwierzęcych
$\mathrm{CO}$ Carbon monoxide/tlenek węgla
EGR Exhaust Gas Recirculation/system recyrkulacji spalin
EL Camelina esters/estry lnianki
ESC European Stationary Cycle/test europejski w warunkach stacjonarnych
ETC European Transient Cycle/test europejski w warunkach nieustalonych
ge
$\mathrm{M}$
$\mathrm{N} \quad$ engine power/moc silnika
NOx nitrogen oxides/tlenki azotu
NRTC Non-Road Transient Cycle/test w warunkach nieustalonych dla silników o przeznaczaniu pozadrogowym
ON diesel oil/olej napedowy
PM particulate matter/cząstki state
THC total hydrocarbons/węglowodory
$\mathrm{V} \quad$ revolution per minute/prędkość obrotowa

\section{Bibliography/Literatura}

[1] Juliszewski T., Zając T.: Biopaliwo rzepakowe, PWRiL, Poznań 2007.

[2] Przemysł i handel naftowy 2009, Polska organizacja przemysłu i handlu naftowego, Raport roczny.

[3] Szlachta Z.: Zasilanie silników wysokoprężnych paliwami rzepakowymi. WKit, Warszawa 2002.

Prof. Andrzej Niewczas, DSc., DEng.-- professor in the Faculty of Transport and Informatics Department at University of Economics and Innovations in Lublin. Prof. dr hab. inż. Andrzej Niewczas - profesor na Wydziale Transportu i Informatyki Wyższej Szkoly Ekonomii i Innowacji w Lublinie. e-mail:a.niewczas@wsei.lublin.pl

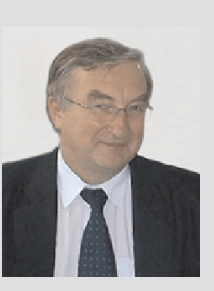

Leszek Gil, DEng. - doctor in the Transport and Informatics Department at University of Economics and Innovations in Lublin.

Dr inż. Leszek Gil - wykładowca na Wydziale Transportu i Informatyki Wyższej Szkoty Ekonomii i Innowacji w Lublinie. e-mail:l.gil@wsei.lublin.p
[4] Gil L.: Badania zużycia tribologicznego elementów układu wtryskowego silnika o zapłonie samoczynnym zasilanego olejami roślinnymi. Rozprawa doktorska, Politechnika Lubelska, Lublin 2011.

[5] Lotko W.: Zasilanie silników wysokoprężnych paliwami węglowodorowymi i roślinnymi, WNT, Warszawa 1997.

[6] Lotko W.: Zasilanie silników spalinowych paliwami alternatywnymi, Wydawnictwo Instytutu Technologii i Eksploatacji, Wyższa Szkoła Inżynierska w Radomiu, Radom 1995.

[7] Ignaciuk P., Gil L., Niewczas A.: Ocena właściwości tribologicznych paliw roślinnych w aspekcie wpływu na proces zużycia aparatury wtryskowej silników o zapłonie samoczynnym, MOTROL - Motoryzacja i Energetyka Rolnictwa. Tom 11C, Lublin 2009.

[8] Ignaciuk P., Gil L., Sarnowski C.: Oil Plants Cultivated in Poland as A Raw Product for The Production of Biofules, Advances in Automotive Engineering. Volume I. Tribun EU, s.171-175, Brno 2008,

Piotr Ignaciuk, DEng. - doctor in the Faculty of Mechanical Engineering at Lublin University of Technology.

Dr inż. Piotr Ignaciuk - adiunkt na Wydziale Mechanicznym Politechniki Lubelskiej.

e-mail: p.ignaciuk@pollub.pl

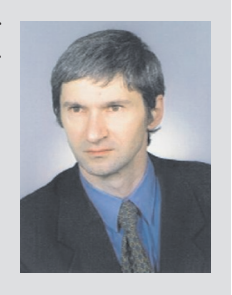

